\title{
РЕАЛІЗАЦІЯ МЕХАНІЗМІВ ДЕРЖАВНОЇ ПІДТРИМКИ РЕГІОНАЛЬНОГО РОЗВИТКУ НА ПРИКЛАДІ МИКОЛАЇВСБКОЇ ОБЛАСТІ
}

Штирьов О.М., канд., наук з держ. упр., доцент, Інститут державного управління, Чорноморський національний університет ім. Петра Могили, м. Миколаїв, Україна

Гіржек $\boldsymbol{A}$. О., аспірант, Інститут державного управління, Чорноморський національний університет ім. Петра Могили, м. Миколаїв, Україна

У статті досліджуються механізми державної підтримки регіонального розвитку, а саме: фінансування з Держсавного фонду регіонального розвитку; субвениія з державного бюджету місиевим бюджетам на формування інфраструктури об'єднаних територіальних громад, субвенція з державного бюджету місиевим бюджетам на здійснення заходів щзодо сочіально-економічного розвитку окремих територій; субвенція з державного бюджету місиевим бюджетам на фінансування заходів сочіально-економічної компенсації ризику населення, яке проживає на території зони спостереження; субвениія з державного бюджету місиевим бюджетам на здійснення заходів, спрямованих на розвиток системи охорони здоров'я у сільській місиевості. Автори аналізують нормативно-правові акти, якими визначено умови та изілі надання субвениій з державного бюджету місиевим бюджетам, а також надання коштів з Державного фонду регіонального розвитку. Крім того подається иікавий досвід щуодо успішного освоєння коштів субвениій з державного бюджету місцевим бюджетам Миколаївської області. На підставі проведеного дослідження зроблені висновки, щзодо позитивного впливу реалізації механізмів державної підтримки регіонального розвитку на об 'єднані територіальні громади загалом і на Миколаївщину зокрема. 
Ключові слова: децеентралізачія; субвенція; територіальні громади; держсавний бюджет; місиевий бюджет; сільська місиевість.

Постановка проблеми у загальному вигляді. У рамках проведення реформи з децентралізації в Україні спостерігається розвиток територій у різних регіонах. Об'єднані територіальні громади (далі - ОТГ) отримали платоспроможні місцеві бюджети, можливість самостійно вирішувати інфраструктурні питання населених пунктів.

Після об’єднання у громадах велику увагу приділили розвитку сільських територій, які 390 -х років минулого століття перебувають у критичному стані. На сьогодні на Миколаївщині в утворених 41 об'єднаних територіальних громадах уже роблять вуличне освітлення, ремонтують дороги, реконструюють будинки культури, школи, дитячі садки, відкривають ЦНАПи тощо. До сіл залучають сімейних лікарів, учителів, яким громада надає житло. Тому, на нашу думку, питання підтримки регіонального розвитку набуває особливого значення в умовах сьогодення і потребує подальшого наукового дослідження.

Формулювання цілей статті (постановка завдання). В процесі дослідження були поставлені наступні завдання:

- дослідити основні механізми державної підтримки регіонального розвитку;

- проаналізувати нормативно-правові акти, які визначають умови та цілі надання субвенцій 3 державного бюджету місцевим бюджетам, а також надання коштів з Державного фонду регіонального розвитку;

- на прикладі Миколаївської області проаналізувати результати щодо практичної реалізації механізмів державної підтримки регіонального розвитку.

Виклад основного матеріалу дослідження. Урядом передбачено чотири основні механізми державної підтримки регіонального розвитку. Зокрема, це Державний фонд регіонального розвитку (далі - ДФРР), субвенція з державного бюджету місцевим бюджетам на формування інфраструктури об'єднаних територіальних громад, 
субвенція з державного бюджету місцевим бюджетам на здійснення заходів щодо соціально-економічного розвитку окремих територій, субвенція 3 державного бюджету місцевим бюджетам на фінансування заходів соціально-економічної компенсації ризику населення, яке проживає на території зони спостереження [2]. Інформацію щодо розподілу коштів серед основних механізмів державної підтримки об'єднаних територіальних громад Миколаївської області в 2016-2018 роках, розміщено в Діаграмі 1.

Діаграма 1

\section{Інформація щодо основних механізмів}

державної підтримки об'сднаних територіальних громад Миколаївської області в 2016-2018 роках, млн грн.

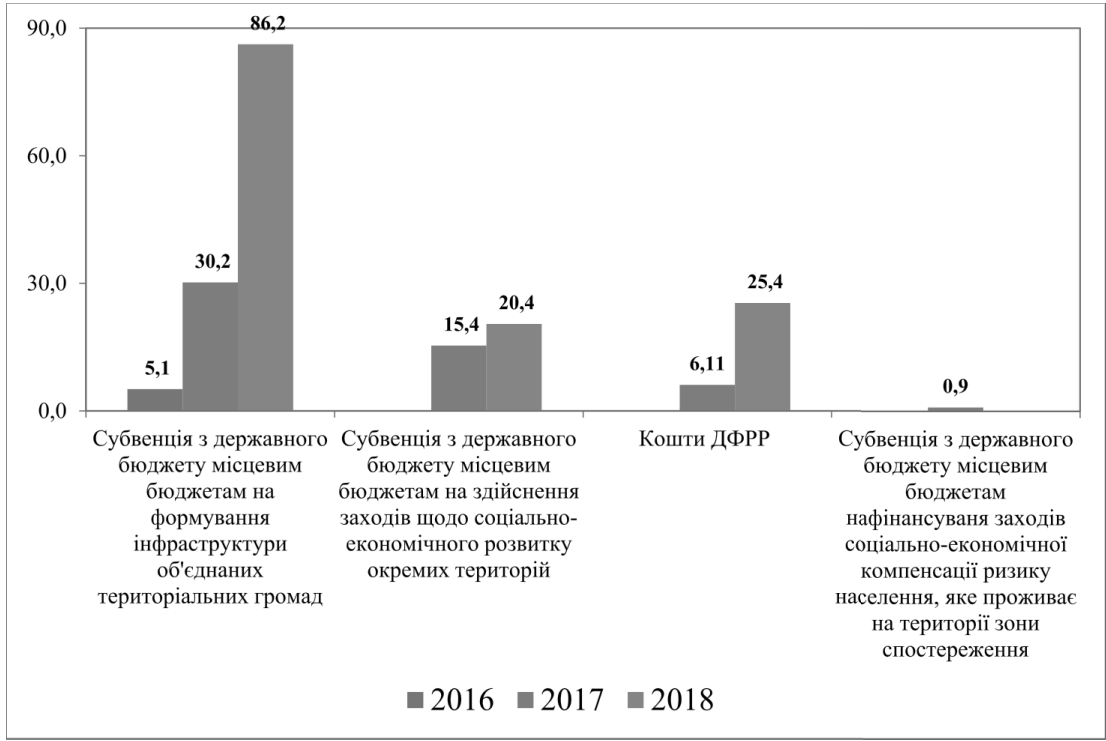

Відповідно до ст. 97 Бюджетного Кодексу України Порядок та умови надання субвенцій 3 державного бюджету місцевим бюджетам визначаються Кабінетом Міністрів України, а субвенція, яка вперше визначена законом про Державний бюджет України, затвер- 
джуються Кабінетом Міністрів України не пізніше 30 днів 3 дня набрання ним чинності.

Субвенції - міжбюджетна трансферти для використання на певну мету в порядку, визначеному органом, який прийняв рішення про надання субвенції [1].

Як відомо, утворені ОТГ формують місцевий бюджет спільно 3 Міністерством фінансів України, оминаючи при цьому районний та обласний рівні. Крім того, місцеві бюджети поповнюються коштами інфраструктурної субвенції, яка покликана стимулювати утворення об'єднаних територіальних громад та розраховується, зважаючи на площу громади та кількість населення. Усі кошти, які надходять до громад, проходять через процедуру Prozorro. В результаті чого ОТГ здешевлюють деякі інфраструктурні проекти на кілька тисяч гривень [8].

Субвенція надається для формування інфраструктури об'єднаної територіальної громади, що належить до комунальної власності, та спрямовується на:

- розроблення проектної, містобудівної та планувальної документації;

- підвищення якості надання адміністративних послуг, зокрема створення, модернізацію центрів надання адміністративних послуг та придбання обладнання і програмного забезпечення;

- створення сучасних систем організації управління громадою комунікаційних мереж, баз даних, систем оповіщення населення;

- реконструкцію, капітальний ремонт, переобладнання, перепрофілювання будівель бюджетних установ 3 метою їх використання відповідно до повноважень та потреб об'єднаних територіальних громад з обов'язковим застосуванням енергоефективних технологій;

- нове будівництво, реконструкцію, капітальний ремонт вулиць, доріг, мостів, переходів комунальної власності, що поліпшують доступність жителів до об'єктів та установ, у яких надаються адміністративні, соціальні та інші послуги;

- закупівлю транспортних засобів для підвезення дітей до навчальних закладів, транспортних засобів спеціального призначення та комплектувальних виробів до них для комунальних підприємств, 
пожежної та спеціальної рятувальної техніки та пожежно-рятувального оснащення, спеціалізованих санітарних транспортних засобів для лікувальних закладів;

- нове будівництво, реконструкцію, капітальний ремонт об'єктів водопостачання та водовідведення, об'єктів поводження з відходами та рекультивацію територій сміттєзвалищ тощо;

- здійснення інших заходів щодо об'єктів комунальної форми власності, які $є$ важливими для посилення спроможності територіальної громади, забезпечення належного рівня безпеки та цивільного захисту;

- погашення в установленому законодавством порядку зареєстрованої органами Казначейства на початок бюджетного періоду бюджетної кредиторської заборгованості місцевих бюджетів, що виникла під час здійснення видатків місцевими бюджетами за рахунок коштів, отриманих 3 державного бюджету за програмою «Субвенція 3 державного бюджету місцевим бюджетам на формування інфраструктури об'єднаних територіальних громад»;

- будівництво, реконструкцію, ремонт та утримання доріг місцевого значення, вулиць і доріг комунальної власності у населених пунктах;

- співфінансування інших програм і проектів, що реалізуються за рахунок коштів державного та місцевих бюджетів.

- капітальний ремонт вулиць і доріг населених пунктів та інших доріг, які є складовими автомобільних доріг державного значення (як співфінансування на договірних засадах) [3].

Умовами надання субвенції $є$ :

- спрямування субвенції на фінансування проектів згідно з планом соціально-економічного розвитку об'єднаної територіальної громади з урахуванням потреб різних соціальних груп з метою забезпечення рівних прав і можливостей жінок і чоловіків та відповідно до напрямів, визначених у пункті 4 цих Порядку та умов, оформлених за формою, встановленою Мінрегіоном, та календарний план реалізації яких становить не більш, як три роки;

- погодження поданого виконавчими комітетами міських, селищних, сільських рад об'єднаних територіальних громад переліку 
проектів, видатки на які здійснюватимуться за рахунок коштів субвенції, з відповідними проектними заявками, складеними за формою, встановленою Мінрегіоном, спеціально утвореною для їх розгляду при Мінрегіоні комісією;

- врахування потреб осіб з інвалідністю та інших маломобільних груп населення під час розроблення проектної документації, а також під час закупівлі транспортних засобів загального користування, шкільних автобусів тощо [3].

У Законі України «Про державний бюджет на 2019 рік» для підтримки сталого розвитку регіонів України передбачено понад 2,1 млрд грн. Ці кошти передбачено на інфраструктурні проекти, які $\epsilon$ стратегічно важливими для територій і забезпечують сталий розвиток громад, підвищують їхню конкурентоспроможність під час реформи місцевого самоврядування й децентралізації [10].

Кошти розподіллено між бюджетами 806 об'єднаних територіальних громад пропорційно до їх площ та кількості сільського населення з рівною вагою обох цих факторів згідно з статтею 10 Закону України «Про добровільне об’ єднання територіальних громад» [11].

Відповідно до розрахунків найбільший обсяг субвенції у 2019 році отримають об'єднані територіальні громади Житомирської 175,3 млн. грн., Дніпропетровської - 174 млн. грн., Хмельницької 145,2 млн. грн., Чернігівської - 134,1 млн. грн. областей.

Станом на 01.01.2019 об’єднані територіальні громади Миколаївської області отримали субвенцію з державного бюджету на формування інфраструктури на загальну суму 121,5 млн. грн.

Цього року субвенція також передбачена для 24 об'єднаних територіальних громад 3 адміністративними центрами у містах обласного значення, де завершився процес приєднання суміжних сільських, селищних територіальних громад відповідно до Закону України «Про добровільне об’ єднання територіальних громад» [14].

Розглянемо розподіл інфраструктурної субвенції по громадам на прикладі Миколаївської області за період 2016-2018 років (Діаграма 2). 
Діаграма 2

Розподіл та фактичне перерахування субвенція 3 державного бюджету місцевим бюджетам на формування інфраструктури об'єднаних територіальних громад Миколаївської області станом на 01.01.2019, млн.грн.

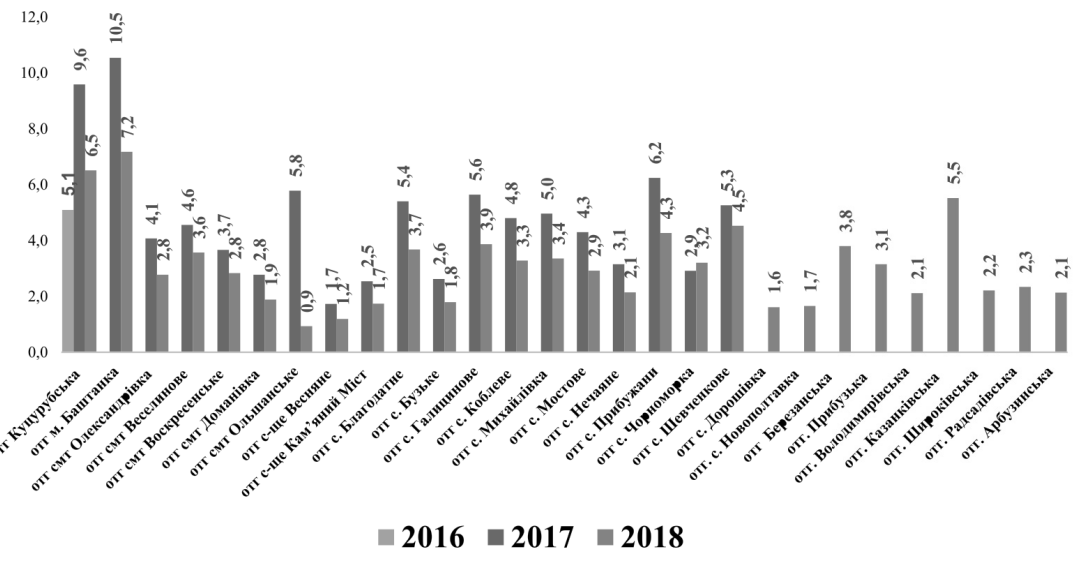

Зазначимо, що за рахунок субвенції на формування інфраструктури об’єднаних територіальних громад за період 2016-2018 років в Миколаївській області по галузі (Діаграма 3):

- «Освіта» було реалізовано 55 проектів, видатки спрямовувалися на капітальний ремонт та реконструкція шкіл, дитячих садків, придбання обладнання в обсязі;

- «Медицина» реалізовано 6 проектів 3 реконструкції лікувальних корпусів лікарень, придбання медичного автомобіля;

- «Культура і спорт» - 21 проект з реконструкції сільських будинків культури, стадіону;

- 65 проектів 3 капітального ремонту дорожнього покриття вулиць, провулків, проїздів, під’їздів, автодоріг;

- 66 проектів з благоустрою території, таких, як капітальний ремонт та реконструкція мережі вуличного освітлення, будівництво, реконструкція та облаштування системи водопроводу, розвідувально-експлуатаційних свердловин, водонапірних башт; 
- придбано спецтехніки для комунальних підприємств в кількості 43 штук;

- 28 інших проектів, таких як, реконструкція нежитлових приміщень (сільські ради, ЦНАП), розробка Генеральних планів, виготовлення містобудівної документації.

Діаграма 3

Інформація про використання у 2016-2018 роках субвенції 3 державного бюджету місцевими бюджетами на формування інфраструктури об'сднаних територіальних громад Миколаївської області за напрямками розподілу (за сферами діяльності), млн.грн.

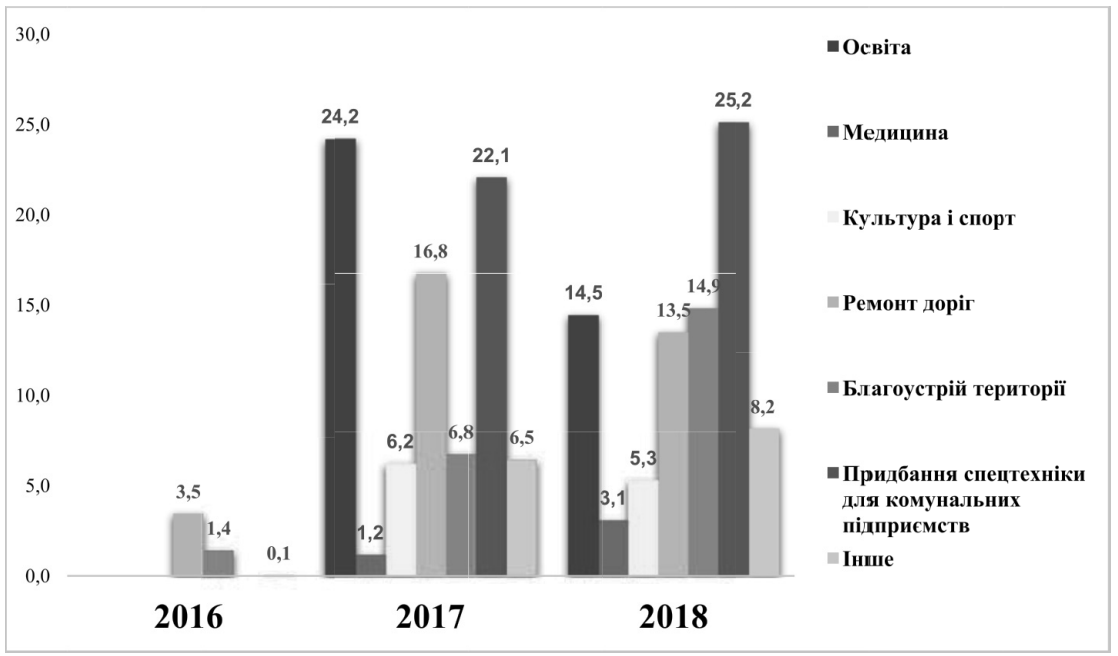

Наступним механізмом державної підтримки регіонального розвитку є фінансування ДФРР. У Миколаївській області відібрано 6 проектів громад, що профінансувалися з ДФРР у 2016-2018 роках на загальну суму майже 31,5 млн грн. Проекти, які надійшли від громад, проходять оцінку в конкурсному відборі. Так, усього на конкурсний відбір 201-2018 років надійшло 46 інвестиційних проектів на суму понад 150 млн грн, серед яких: добудова об'єктів 
незавершеного будівництва, які реалізовувалися за рахунок коштів ДФРР у попередні роки й мають пріоритет першочергового фінансування; проекти з підтримки добровільно об'єднаних і співробітництва територіальних громад; проекти, що передбачають заходи 3 енергозбереження та енергоефективності закладів освіти й охорони здоров'я; проекти з розвитку спортивної інфраструктури та розбудови мережі сервісних центрів надання адміністративних послуг; проекти $з$ придбання техніки для організації збору ТПВ, шкільного й медичного обладнання, шкільних автобусів; проекти з будівництва, реконструкції, модернізації.

Згідно з індивідуальними оцінками проектів, сформовано загальний рейтинговий список проектів, що брали участь у попередньому конкурсному відборі. Оцінювали проекти за п'ятьома критеріями: вплив на розвиток громади або регіону; ступінь впливу на розв'язання проблеми; інноваційність; місцеві бюджети і їхня потенційна спроможність; соціально-економічна спрямованість проекту.

Це так звана «субвенція для регіональної єдності держави», яка розподіляється прозоро між регіонами відповідно до формули, що враховує їхній економічний стан, згідно з чіткою формулою, яка залежить від чисельності населення (80 \% коштів) і соціально-економічного розвитку регіону (валового регіонального продукту на душу населення - 20 \% коштів) [7].

Державний фонд регіонального розвитку сьогодні фінансує проекти відповідно до стратегій розвитку регіонів і Державної стратегії регіонального розвитку України на період до 2020 року. 3 обласного рівня результати для схвалення передаються на рівень національний (міжвідомча комісія Мінрегіону України), а КМУ затверджує цей перелік. Отже, сьогодні створено серйозну інституційну й законодавчу базу, працює прозора онлайн-платформа ДФРР, де можна бачити всі подані проекти, усі регіони отримали рівні можливості на регіональний розвиток.

У цьому році в більшості регіонах країни проекти, які були відібрані для фінансування з ДФРР, важко назвати інноваційними чи економічно ефективними. Це в першу чергу зумовлено необхід- 
ністю невідкладного фінансування важливих соціальних об'єктів: ремонтування шкіл, дитсадків, спортивних комплексів, лікарень. Наприклад, у м. Баштанка та селах Добре та Новогригорівка було переоснащенні насосні станції водопостачання II та III підйому, в Кам’яномістівській ОТГ будівництво насосної станції III підйому 3 резервуарами запасу води. Обласні заклади охорони здоров'я потребують капітальних ремонтів і обладнання. У такому випадку голови сільських, селищних, міських рад змушені звертати увагу саме на такі проблеми, які потребують негайного рішення в громаді.

Після утворення Куцурубської сільської ОТГ Миколаївської області місцева влада вирішила подбати насамперед про дітей. У результаті співпраці з ДФРР до кінця 2016 р. вдалося облаштувати три дитячі майданчики в селах Куцуруб, Яселка та Іванівка Куцурубської ОТГ. Власне кажучи, це були 3 окремі проекти побудови дитячих майданчиків. Кожен коштував 188,8 тис. грн., з яких 169,9 тис. грн. надавалося ДФРР, 18,9 тис. грн. йшло з місцевого бюджету. Створення дитячих майданчиків почалося в жовтні й завершилося в грудні 2016 р. У с. Куцуруб проживає 2285 жителів, серед яких 137 дітей дошкільного віку. Село протяжністю 3 км, тут лише один дитячий майданчик, якого замало для такої кількості дітей. У с. Яселка 270 жителів, серед яких 29 дітей дошкільного віку, а в с. Іванівці 1300 жителів, з яких 64 дитини дошкільного віку [8].

Наступним різновидом механізмів підтримки регіонального розвитку є субвенція з державного бюджету місцевим бюджетам на здійснення заходів щодо соціально-економічного розвитку окремих територій.

24 червня 2019 року, відповідно до наданого Міністерством фінансів України територіального розподілу розпису державного бюджету на виконання розпорядження Кабінету Міністрів України від 5 червня 2019 № 365-р «Деякі питання розподілу у 2019 році субвенції 3 державного бюджету місцевим бюджетам на здійснення заходів щодо соціально-економічного розвитку окремих територій», Казначейством 3 загального фонду державного бюджету перераховано місцевим бюджетам кошти субвенції на здійснення заходів щодо соціально-економічного розвитку окремих територій у сумі 981,7 млн грн. [5] 
Розподіл у 2019 році субвенції $з$ державного бюджету місцевим бюджетам на здійснення заходів щодо соціально-економічного розвитку окремих територій між місцевими бюджетами за об'єктами (заходами) викладено у Таблиці 1[5].

Таблиця 1

\section{Розподіл у 2019 році субвенції з державного бюджету місцевим бюджетам на здійснення заходів щодо соціально-економічного розвитку окремих територій між місцевими бюджетами за об'сктами (заходами)}

\begin{tabular}{|c|c|}
\hline $\begin{array}{c}\text { Назва місцевого бюджету адміністративно- } \\
\text { територіальної одиниці }\end{array}$ & $\begin{array}{c}\text { Обсяг субвенції } \\
\text { (усього), тис. } \\
\text { гривень }\end{array}$ \\
\hline Бюджет м. Вознесенська & 488 \\
\hline $\begin{array}{l}\text { Бюджет Баштанської міської об’єднаної територіальної } \\
\text { громади }\end{array}$ & 1547 \\
\hline Бюджет м. Миколаєва & 40709,8 \\
\hline Обласний бюджет Миколаївської області & 717 \\
\hline Районний бюджет Березнегуватського району & 1197 \\
\hline Районний бюджет Березанського району & 976 \\
\hline Районний бюджет Єланецького району & 974 \\
\hline Районний бюджет Веселинівського району & 973 \\
\hline Районний бюджет Доманівського району & 974 \\
\hline $\begin{array}{llll}\text { Бюджет } & \text { Галицинівської } & \text { сільської } & \text { об’єднаної } \\
\text { територіальної громади }\end{array}$ & 3 \\
\hline Районний бюджет Вітовського району & 22 \\
\hline $\begin{array}{lll}\text { Бюджет Шевченківської } & \text { сільської } & \text { об’єднаної } \\
\text { територіальної громади } & & \\
\end{array}$ & 25,2 \\
\hline $\begin{array}{lll}\text { Бюджет Воскресенської } \\
\text { територіальної громади }\end{array}$ & 65 \\
\hline Бюджет м. Южноукраїнська & 3958 \\
\hline Районний бюджет Миколаївського району & 201 \\
\hline
\end{tabular}


Продовження табл. 1

\begin{tabular}{|c|c|}
\hline $\begin{array}{l}\text { Бюджет Радсадівської сільської об’єднаної територіальної } \\
\text { громади }\end{array}$ & 86 \\
\hline $\begin{array}{l}\text { Бюджет Веснянської сільської об’єднаної територіальної } \\
\text { громади }\end{array}$ & 43 \\
\hline $\begin{array}{l}\text { Бюджет Ольшанської селищної об’єднаної територіальної } \\
\text { громади }\end{array}$ & 22 \\
\hline $\begin{array}{l}\text { Бюджет Нечаянської сільської об’єднаної територіальної } \\
\text { громади }\end{array}$ & 96 \\
\hline $\begin{array}{l}\text { Бюджет Михайлівської } \\
\text { територіальної громади }\end{array}$ & 54 \\
\hline $\begin{array}{l}\text { Бюджет Чорноморської } \quad \text { сільської } \quad \text { об’єднаної } \\
\text { територіальної громади }\end{array}$ & 54 \\
\hline $\begin{array}{l}\text { Бюджет Куцурубської сільської об’єднаної територіальної } \\
\text { громади }\end{array}$ & 119 \\
\hline Районний бюджет Очаківського району & 40 \\
\hline Бюджет м. Очакова & 96 \\
\hline Районний бюджет Вознесенського району & 134 \\
\hline $\begin{array}{l}\text { Бюджет Березанської селищної об’єднаної територіальної } \\
\text { громади }\end{array}$ & 25 \\
\hline Районний бюджет Снігурівського району & 500 \\
\hline Районний бюджет Врадіївського району & 373,7 \\
\hline Районний бюджет Первомайського району & 251,3 \\
\hline
\end{tabular}

Вищезазначені кошти спрямовується на:

- будівництво, реконструкцію, капітальний ремонт об'єктів інфраструктури комунальної власності (за винятком адміністративних будинків);

- здійснення екологічних та природоохоронних заходів;

- придбання обладнання для установ соціально-культурної сфери комунальної власності та комунального транспорту, зокрема спеціального призначення;

- здійснення заходів, пов'язаних з відселенням громадян із житлових будинків, що перебувають в аварійному стані; 
- розв’язання проблем окремих адміністративно-територіальних одиниць (малих міст, шахтарських та гірських населених пунктів);

- погашення бюджетної заборгованості місцевих бюджетів, що виникла під час здійснення видатків місцевими бюджетами за рахунок коштів, отриманих 3 державного бюджету за програмами «Субвенція $з$ державного бюджету місцевим бюджетам на здійснення заходів щодо соціально-економічного розвитку окремих територій», «Субвенція з державного бюджету місцевим бюджетам на соціально-економічний розвиток», «Субвенція з державного бюджету місцевим бюджетам на реалізацію пріоритетів розвитку регіонів»;

- проведення робіт з газифікації;

- здійснення заходів з енергозбереження;

- здійснення спільних заходів, передбачених угодами щодо регіонального розвитку, які укладені відповідно до Закону України "Про стимулювання розвитку регіонів";

- здійснення заходів щодо соціально-економічного розвитку регіонів;

- будівництво, реконструкцію об'єктів освіти та охорони здоров'я зі ступенем будівельної готовності не менше 90 \% або введення їх в експлуатацію у 2016-2017 роках;

- будівництво, реконструкцію та капітальний ремонт доріг;

- реалізацію проектів з енергоефективності та енергозбереження;

- виготовлення проектної документації;

- будівництво, реконструкцію, капітальний ремонт об'єктів 3 виготовленням відповідної проектної документації на виконання зазначених видів робіт [12].

Слід відмітити, що зустрічаються випадки в повному обсязі коштів субвенцій виділених 3 державного бюджету місцевим бюджетам, що обумовлено економією коштів по фактично виконаних роботах порівняно 3 кошторисною вартістю, обмеженими термінами будівництва відповідно до погодних умов, необхідністю коригуванням проектно-кошторисних документацій, заміни проектних рішень та надходженням коштів 3 державного бюджету наприкінці року.

Ще одним специфічним механізмом підтримки регіонального розвитку є субвенція з державного бюджету місцевим бюджетам на 
фінансування заходів соціально-економічної компенсації ризику населення, яке проживає на території зони спостереження. Дана субвенція надається бюджетам адміністративно-територіальних одиниць, на територію яких поширюється зона спостереження атомних електростанцій державного підприємства «Національна атомна енергогенеруюча компанія “Енергоатом”». Розподіл субвенції субвенція $з$ державного бюджету місцевим бюджетам на фінансування заходів соціально-економічної компенсації ризику населення, яке проживає на території зони спостереження Южно-Української АЕС, на 2019 рік [9] викладено в Таблиці 2.

Таблиця 2

\section{Розподіл субвенції 3 державного бюджету місцевим бюджетам на фінансування заходів соціально-економічної компенсації ризику населення, яке проживає на території зони спостереження Южно-Української АЕС, на 2019 рік}

\begin{tabular}{|l|l|}
\hline \multicolumn{1}{|c|}{$\begin{array}{c}\text { Назва місцевого бюджету адміністративно- } \\
\text { територіальної одиниці }\end{array}$} & $\begin{array}{c}\text { Обсяг субвенції, } \\
\text { тис. гривень }\end{array}$ \\
\hline Обласний бюджет Миколаївської області & 8745 \\
\hline Районний бюджет Арбузинського району & 3146,3 \\
\hline Районний бюджет Братського району & 1579,6 \\
\hline Районний бюджет Вознесенського району & 2384,1 \\
\hline Районний бюджет Доманівського району & 2895,7 \\
\hline Районний бюджет Первомайського району & 619,5 \\
\hline Бюджет м. Вознесенська & 5407,2 \\
\hline Бюджет м. Южноукраїнська & 4372,5 \\
\hline
\end{tabular}

Зазначимо, що даний різновид субвенції спрямовується насамперед на:

- реалізацію проектів нового будівництва, реконструкції, капітального ремонту, в тому числі виготовлення проектної документації, захисних споруд цивільного захисту, технічну інвентаризацію, яких проведено відповідно до законодавства; 
- закупівлю засобів індивідуального захисту органів дихання та препаратів стабільного йоду;

- навчання населення користуванню об'єктами спеціальної соціальної інфраструктури та засобами індивідуального захисту органів дихання;

- фінансування у разі потреби об'єктів спеціальної соціальної інфраструктури, у тому числі реалізація проектів будівництва, реконструкції, капітального та поточного ремонту таких об'єктів, зокрема навчальних закладів, закладів охорони здоров'я, культури, фізичної культури та спорту, об'єктів житлово-комунального господарства, автомобільних доріг, систем зв'язку;

- погашення кредиторської заборгованості, що утворилася за субвенцією у попередніх роках і зареєстрована органами Казначейства [13].

Слід зазначити, що крім розглянутих основних механізмів державної підтримки регіонального розвитку, існують і інші механізми, які хоч і передбачають менші обсяги фінансування, проте мають не менше значення для населення ОТГ. В цьому контексті, доцільно виділити субвенцію $з$ державного бюджету місцевим бюджетам на здійснення заходів, спрямованих на розвиток системи охорони здоров’я у сільській місцевості. На нашу думку, зазначений механізм заслуговує особливої уваги, враховуючи положення ст. 3 Конституції України, яка передбачає, що життя і здоров'я людини є найвищою соціальною цінністю [6].

Крім того необхідно зазначити положення ст. 49 Конституції України, яка гарантує право на охорону здоров'я, медичну допомогу та медичне страхування.

Охорона здоров'я забезпечується державним фінансуванням відповідних соціально-економічних, медико-санітарних і оздоровчо-профілактичних програм.

Держава створює умови для ефективного і доступного для всіх громадян медичного обслуговування. У державних і комунальних закладах охорони здоров'я медична допомога надається безоплатно; існуюча мережа таких закладів не може бути скорочена. Держава сприяє розвиткові лікувальних закладів усіх форм власності [6]. 
Відповідно до Постанови КМУ від 6 грудня 2017 р. № 983 «Деякі питання надання субвенції 3 державного бюджету місцевим бюджетам на здійснення заходів, спрямованих на розвиток системи охорони здоров'я у сільській місцевості», було запроваджено субвенцію на розвиток системи охорони здоров'я в сільській місцевості.

Субвенція спрямовується на:

- реалізацію проектів будівництва (нове будівництво, реконструкцію, капітальний ремонт, в тому числі виготовлення проектної документації) комунальних закладів охорони здоров'я у сільській місцевості з урахуванням потреб населення у медичному обслуговуванні, необхідності забезпечення належної якості такого обслуговування, своєчасності, доступності для громадян, ефективного використання матеріальних, трудових і фінансових ресурсів;

- придбання медичного обладнання, устаткування та засобів відповідно до примірного табеля матеріально-технічного оснащення закладів охорони здоров'я та фізичних осіб - підприємців, які надають первинну медичну допомогу, затвердженого МO3 та оприлюдненого на його офіційному веб-сайті, в обсязі, необхідному для надання населенню гарантованого рівня медичної допомоги, зокрема медичної апаратури, обладнання;

- розвиток телекомунікаційної інфраструктури, включаючи забезпечення закладів охорони здоров'я широкосмуговим доступом до Інтернету, забезпечення сучасними технічними та інформаційно-програмними засобами для функціонування електронної системи охорони здоров'я та телемедицини;

- здійснення заходів, пов'язаних із забезпечення службовим житлом (в тому числі будівництво і придбання) та службовим автотранспортом, який відповідає критеріям, визначеним MO3 (у тому числі для обслуговування мешканців віддалених населених пунктів, що розташовані на території обслуговування закладу охорони здоров'я), медичних працівників комунальних закладів охорони здоров'я, що працюють у сільській місцевості.

Суб'єкти, на фінансування об'єктів яких залучається субвенція, забезпечують їх подальше власне фінансування або утримання за рахунок коштів місцевих бюджетів. 
Субвенція надається за умови, що:

- план реалізації не повинен становити більш як два роки;

- враховуються потреби осіб з інвалідністю та інших маломобільних груп населення під час розроблення проектної документації та реалізації проектів;

- проекти, що реалізуються за рахунок субвенції, підлягають співфінансуванню з місцевих бюджетів на рівні не менше ніж 10 відсотків їх вартості, за винятком проектів, які передбачають здійснення заходів, пов'язаних із забезпеченням службовим автотранспортом медичних працівників комунальних закладів охорони здоров’я, що працюють у сільській місцевості [4].

Так, в Миколаївській області за рахунок виділених коштів розпочали будівництво 6 амбулаторій первинної медико-санітарної допомоги в 5 ОТГ (Таблиця 3).

Таблиця 3

Інформація, щодо стану реалізації проектів нового будівництва, що фінансуються за рахунок субвенції 3 державного бюджету місцевим бюджетам на здійснення заходів, спрямованих на розвиток системи охорони здоров'я у сільській місцевості за станом на 01.01.2019 p.

\begin{tabular}{|c|c|c|c|c|c|c|c|c|c|c|c|c|c|}
\hline \multirow[t]{2}{*}{\begin{tabular}{l|l} 
\\
$/ n$ \\
$z / n$
\end{tabular}} & \multirow[b]{2}{*}{ 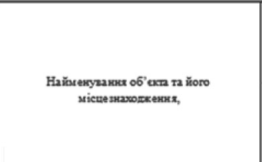 } & \multirow{2}{*}{ 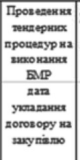 } & \multirow{2}{*}{ 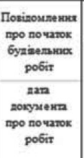 } & \multirow{2}{*}{ 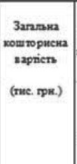 } & \multirow{2}{*}{ 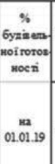 } & \multicolumn{3}{|c|}{ 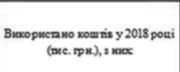 } & \multicolumn{5}{|c|}{ 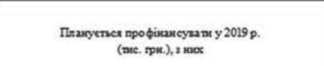 } \\
\hline & & & & & & Besoro & 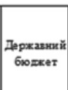 & 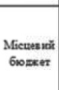 & Besoro & 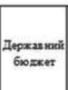 & $\begin{array}{l}\text { Misuesuăt } \\
6 \text { rogxer }\end{array}$ & 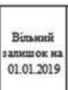 & 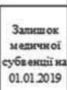 \\
\hline 1 & 2 & 3 & 4 & 5 & 6 & 7 & 8 & 9 & & 12 & & 14 & \\
\hline & BCboro: & . & & 48387,0 & & 150660 & 12978,0 & 2088,0 & 28027,7 & 23869,7 & 4168,0 & 243238 & 110.8 \\
\hline 1 & 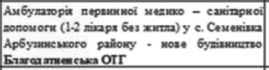 & \begin{tabular}{|c|} 
Na15 ain \\
15.11 .2018 \\
\end{tabular} & 23.112018 & 734,8 & 395\% & 2939,6 & 2886,1 & 353,5 & 3593,6 & 3047,6 & 545,0 & 372,4 & 23,0 \\
\hline 2 & 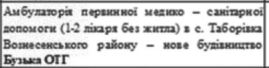 & \begin{tabular}{|l|} 
Sa17 nin \\
21112018
\end{tabular} & 23.112018 & 7219,1 & $38,6 \%$ & 2785,2 & 2469,3 & 3159 & 3732,8 & 3164,4 & 568,4 & 6532,6 & \\
\hline 3 & 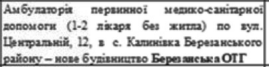 & \begin{tabular}{|l|} 
Nhil4siz \\
30.10 .2018
\end{tabular} & 06.11 .2018 & 7845,7 & $193 \%$ & 1455,1 & 14498 & 305,3 & 5112,9 & 483,9 & 629,0 & 5526,5 & 82,9 \\
\hline 4 & 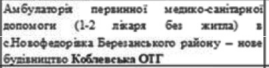 & \begin{tabular}{|l|} 
Na122ie \\
30.10 .2018
\end{tabular} & 0.112018 & 7804,7 & $188 \%$ & 14652 & 11498 & 315,4 & 5135,0 & 483,9 & 651,1 & 2635,8 & 25 \\
\hline 5 & 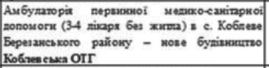 & $\underset{\substack{\text { Nal1 ain } \\
31.10 .2018}}{ }$ & 06.11 .2018 & 10087,6 & $22,0 \%$ & 2219,7 & 18128 & 4069 & 708,9 & 6866,4 & 842,5 & 2635,8 & 25 \\
\hline & 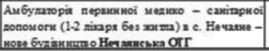 & \begin{tabular}{|l|l|} 
Ne19is \\
14.112018 \\
\end{tabular} & 19.11 .2018 & 8285,1 & 50,6\% & 4201,1 & 3810,2 & 390,9 & 2744,5 & 1823,5 & 921,0 & 3280,9 & 0,0 \\
\hline
\end{tabular}


Висновки. У результаті фінансової децентралізації об’єднані територіальні громади отримали додатковий фінансовий ресурс, завдяки чому загальний обсяг їхніх бюджетів зріс у десятки разів. Зокрема, сьогодні на Миколаївщині функціонує 41 об’єднана територіальна громада. Вирішення комплексу проблем, що виникають на місцевому рівні призводять до значної оптимізації бюджетних відносини та зміцнюють економічну самостійність адміністративно-територіальних одиниць. А це, своєю чергою, призводить до зростання рівня політичної незалежності та фінансового забезпечення місцевого самоврядування, сприятиме розбудові демократичної держави.

Будучи головним ініціатором процесів децентралізації, держава активно підтримує регіональний розвиток, зокрема шляхом реалізації розглянутих у статті механізмів:

- субвенція 3 державного бюджету місцевим бюджетам на формування інфраструктури об'єднаних територіальних громад;

- фінансування з Державного фонду регіонального розвитку;

- субвенція 3 державного бюджету місцевим бюджетам на здійснення заходів щодо соціально-економічного розвитку окремих територій;

- субвенції з державного бюджету місцевим бюджетам на фінансування заходів соціально-економічної компенсації ризику населення, яке проживає на території зони спостереження;

- субвенції з державного бюджету місцевим бюджетам на здійснення заходів, спрямованих на розвиток системи охорони здоров'я у сільській місцевості.

Державна підтримка в вигляді субвенцій з державного бюджету місцевим бюджетам вирішує соціально-побутові питання для комфортного проживання населення, таких як: капітальний ремонт та реконструкція шкіл, дитячих садків, придбання обладнання, реконструкція лікувальних корпусів лікарень, придбання медичного автомобіля; реконструкції сільських будинків культури, стадіонів; капітальний ремонту дорожнього покриття вулиць, провулків, проїздів, під'їдів, автодоріг; капітальний ремонт та реконструкція мережі вуличного освітлення, будівництво, реконструкція та облаштування 
системи водопроводу, розвідувально-експлуатаційних свердловин, водонапірних башт, придбання спецтехніки для комунальних, виготовлення містобудівної документації тощо.

Так, завдяки реалізації проектів за рахунок субвенцій з державного бюджету місцевим бюджетам підвищується громадська довіра до обраних ними органів та посадових осіб, що позитивно впливає на формування громадської самосвідомості жителів та на активізацію їхньої безпосередньої участі у вирішенні питань місцевого значення, активізується управлінська та господарська функції місцевої влади, крім того, все чіткішими та виразнішими стають практичні дії органів місцевого самоврядування стосовно забезпечення розвитку всіх населених пунктів, з яких сформувалася громада.

Варто зазначити, що сьогодні в більшості регіонах країни проекти, які були відібрані для фінансування з ДФРР, важко назвати інноваційними чи економічно ефективними, адже в основному це «латання дір». Це зумовлено тим, що все ще залишається актуальним фінансування важливих соціальних об’єктів: ремонтування шкіл, дитсадків, спортивних комплексів, лікарень тощо. У такому випадку голови сільських, селищних, міських рад змушені звертати увагу саме на такі проблеми, які потребують негайного рішення в громаді.

Представники влади на рівні регіону все частіше закликають органи місцевого самоврядування приймати активну участь у розробці та створенні нових проектів та програм, які б торкались та/ або комплексно розв'язували основні проблеми, наприклад, проекти, що створюють умови для розвитку бізнесу. У наступному році завдання буде сформульоване таким чином, щоб презентувались якомога більш якісні проекти, які б дали змогу чітко зрозуміти для всіх ключові проблеми й потенціал регіону його перспективи, що в свою чергу, дасть змогу послідовно розв'язувати проблеми та надасть можливість реалізовувати потенціал громади. В ідеалі проекти регіонального розвитку мають створити умови для розвитку бізнесу, який заплатить податки, з яких уже «лататимуться діри».

\section{Стаття надійшла до редакції: 03.06.19}




\section{IMPLEMENTATION OF STATE SUPPORT MECHANISMS FOR REGIONAL DEVELOPMENT ON THE EXAMPLE OF THE NIKOLAEV REGION}

Oleksandr Shtyrov, $\mathrm{PhD}$ in Public Administration, Associate Professor, Institute of Public Administration, Petro Mohyla Black Sea National University, Mykolaiv, Ukraine

Artem Hirzhev, Postgraduate student at the Institute of Public Administration, Petro Mohyla Black Sea National University, Mykolaiv, Ukraine

The article examines mechanisms of state support for regional development, namely: financing from the State Regional Development Fund; subsidy from the state budget to the local budgets for the formation of infrastructure of the united territorial communities; a subsidy from the state budget to local budgets for financing measures of socio-economic risk compensation of the population living in the territory of the surveillance zone; subsidy from the state budget to local budgets for the implementation of measures aimed at developing the health care system in rural areas. The use of state subsidies such as subsidies from the state budget to local budgets for the formation of infrastructure of united territorial communities, subsidies from the state budget to local budgets for the implementation of measures for the socio-economic development of individual territories councils and village, settlement, city goals, subsidies from the state budget to the local budgets for financing social and economic compensation of the population risk residing on the territory of the surveillance zone, funds from the State Regional Development Fund. The authors analyze the legal acts, which define the conditions and goals of providing state budget subsidies to local budgets, as well as providing funds from the State Regional Development Fund. In addition, interesting experience is presented regarding the successful development of subsidies from the state budget to the local budgets of the Mykolaiv region. On the basis of the conducted research, conclusions were drawn regarding the positive 
impact of the implementation of mechanisms of state support for regional development on the united territorial communities in general and on Mykolayiv region in particular.

Keywords: decentralization; subvention; territorial communities; National budget; local budget; countryside.

\section{Received: 03.06.19}

\section{References}

1. Biudzhetnyi kodeks Ukrainy [Budget Code of Ukraine]. (n.d.). zakon. rada.gov.ua Retrieved from http://zakon.rada.gov.ua/laws/show/2456-17 [in Ukranian].

2. Detsentralizatsiia: novi zakony - novi mozhlyvosti dlia hromad [Decentralization: New laws - new opportunities for communities]. decentralization.gov.ua Retrieved from https://decentralization.gov.ua/ news/4680 [in Ukranian].

3. Postanova Kabinetu ministriv Ukrainy «Deiaki pytannia nadannia subventsii $\mathrm{z}$ derzhavnoho biudzhetu mistsevym biudzhetam na formuvannia infrastruktury obiednanykh terytorialnykh hromad» [Resolution of the Cabinet of Ministers of Ukraine «Some issues of granting a subsidy from the state budget to local budgets for forming the infrastructure of the united territorial communities»]. zakon.rada.gov.ua Retrieved from http://zakon.rada.gov.ua/ laws/show/200-2016-\%D0\%BF\#n11 [in Ukranian].

4. Postanova Kabinetu ministriv Ukrainy «Deiaki pytannia nadannia subventsii $\mathrm{z}$ derzhavnoho biudzhetu mistsevym biudzhetam na zdiisnennia zakhodiv, spriamovanykh na rozvytok systemy okhorony zdorovia u silskii mistsevosti» [Resolution of the Cabinet of Ministers of Ukraine «Some issues of granting a subsidy from the state budget to local budgets for the implementation of activities aimed at developing the health system in rural areas»]. zakon.rada. gov.ua Retrieved from http://zakon.rada.gov.ua/laws/show [in Ukranian].

5. 5.Postanova Kabinetu ministriv Ukrainy «Deiaki pytannia nadannia subventsii z derzhavnoho biudzhetu mistsevym biudzhetam na zdiisnennia zakhodiv, spriamovanykh na rozvytok systemy okhorony zdorovia u silskii mistsevosti» [Ordinance of the Cabinet of Ministers of Ukraine «Some issues 
of distribution of state budget subsidies to local budgets in 2019 for the implementation of activities for socio-economic development of individual territories»]. zakon.rada.gov.ua Retrieved from http://zakon.rada.gov.ua/laws/ show/365-2019-p [in Ukranian].

6. 6.Zakon Ukrainy «Konstytutsiia Ukrainy» [«Constitution of Ukraine. Law of Ukraine»]. zakon.rada.gov.ua Retrieved from http://zakon2.rada.gov.ua/ laws/show/ [in Ukranian].

7. Palchuk V. Biudzhety mistsevykh rad: postulatsiia ta stvorennia $\mathrm{v}$ suchasnykh reformakh detsentralizatsii [Local Council Budgets: Postulates and Dissemination in the Process of Decentralization Reforms]. Retrieved from http://nbuviap.gov.ua/images/ukraine/2017/ukr12.pdf [in Ukranian].

8. Palchuk V., (2017). Biudzhety mistsevykh rad: postulatsiia ta stvorennia $\mathrm{v}$ suchasnykh reformakh detsentralizatsii [Local council budgets: revenues and expenditures in the process of decentralization reform]. Ukraina: podii, fakty, komentari - Ukraine: events, facts, comments, 12. 41-52. Retrieved from http:// nbuviap.gov.ua/images/ukraine/2017/ukr12.pdf [in Ukranian].

9. Palchuk V., (2017). Biudzhetna samodostatnist i realizatsiia infrastrukturnykh proektiv u rehionakh Ukrainy [Budget self-sufficiency and implementation of infrastructure projects in the regions of Ukraine] Ukraina: podii, fakty, komentari - Ukraine: events, facts, comments, 11.31-42. Retrieved from http://nbuviap.gov.ua/images/ukraine/2017/ukr11.pdf [in Ukranian].

10. Postanova Kabinetu ministriv Ukrainy Pro vnesennia zmin do Poriadku ta umov nadannia subventsii z derzhavnoho biudzhetu mistsevym biudzhetam na finansuvannia zakhodiv sotsialno-ekonomichnoi kompensatsii ryzyku naselennia, yake prozhyvaie na terytorii zony sposterezhennia : vid 3 kvitnia 2019 r. \# 288 [Resolution of the Cabinet of Ministers of Ukraine On amendments to the Procedure and conditions for granting a subsidy from the state budget to local budgets to finance measures of socio-economic compensation for the risk of the population living in the territory of the surveillance zone dated April 3, 2019, No. 288] Retrieved from https://zakon.rada.gov.ua/laws/show/288-2019 [in Ukranian].

11. Zakon Ukrainy Pro Derzhavnyi biudzhet Ukrainy na 2019 rik vid 23.11.2018 roku \# 2629-VIII [Law of Ukraine About the State Budget of Ukraine for 2019 dated 23.11.2018 \# 2629-VIII] Retrieved from https://zakon. rada.gov.ua/laws/show/2629-19 [in Ukranian]. 
12. Zakon Ukrainy Pro dobrovilne obiednannia terytorialnykh hromad vid 05.02.2015r., \# 157-VIII [Law of Ukraine About the About voluntary association of territorial communities dated 05.02.2015, \# 157-VIII] Retrieved from http:// zakon4.rada.gov.ua/laws/show/157-viii [in Ukranian].

13. Postanova Kabinetu ministriv Ukrainy Pro zatverdzhennia Poriadku ta umov nadannia subventsii $\mathrm{z}$ derzhavnoho biudzhetu mistsevym biudzhetam na zdiisnennia zakhodiv shchodo sotsialno-ekonomichnoho rozvytku okremykh terytorii vid 6 liutoho 2012 r. \# 106 [On Approval of the Procedure and Conditions for Granting a State Budget Subsidy to Local Budgets for Implementation of Measures for the Socio-Economic Development of Individual Territories dated February 6, 2012 \# 106] Retrieved from http://zakon.rada.gov.ua/laws/ show/106-2012 [in Ukranian].

14. Postanova Kabinetu ministriv Ukrainy Pro zatverdzhennia Poriadku ta umov nadannia subventsii $\mathrm{z}$ derzhavnoho biudzhetu mistsevym biudzhetam na finansuvannia zakhodiv sotsialno-ekonomichnoi kompensatsii ryzyku naselennia, yake prozhyvaie na terytorii zony sposterezhennia vid 6 liutoho 2012 r. \# 106 [On approval of the Procedure and conditions for granting a subsidy from the state budget to the local budgets for financing measures of socio-economic risk compensation of the population living in the territory of the surveillance zonedated February 6, 2012 \# 106] Retrieved from http://zakon. rada.gov.ua/laws/show/ru/91-2012-\# [in Ukranian].

15. Rozporiadzhennia Kabinetu ministriv Ukrainy Pro zatverdzhennia rozpodilu obsiahu subventsii z derzhavnoho biudzhetu mistsevym biudzhetam na formuvannia infrastruktury obiednanykh terytorialnykh hromad u 2019 rotsi: vid 24 kvitnia 2019 r. \# 280-r [Ordinance of the Cabinet of Ministers of Ukraine On approving the allocation of subvention from the state budget to local budgets for the formation of infrastructure of the united territorial communities in 2019: No. 280-r of April 24, 2019] Retrieved from http://zakon.rada.gov.ua/laws/ show/280-2019 [in Ukranian]. 


\section{Відомості про авторів / Information about the Authors}

Штирьов Олександр Миколайович: Чорноморський національний університет ім. Петра Могили: вул. 68 десантників 10, Миколаїв, 54003, Україна.

Oleksandr Shtyrov: Petro Mohyla Black Sea National University: 68 Desantnykiv str. 10, Mykolaiv, 54003, Ukraine.

ORCID. ORG./ 0000-0002-7627-3721

\section{E-mail: bratislava@ukr.net}

Гіржев Артем Олександрович: Чорноморський національний університет ім. Петра Могили: вул. 68 десантників 10, Миколаїв, 54003, Україна.

Artem Hirzhev: Petro Mohyla Black Sea National University: 68 Desantnykiv str. 10, Mykolaiv, 54003, Ukraine.

ORCID. ORG./ 0000-0002-6516-0713

E-mail: a.hirzhev@ukr.net 